\title{
Characteristics of the Concept "War" in Modern Russian Linguistic Culture
}

\author{
Yulia Pogrebnyak ${ }^{1, *}$ Natalia Fursova $^{2}$ Evgenia Nesterova $^{2}$ Marina Vazhenina $^{2}$ \\ Olga Nozdryuk ${ }^{2}$
}

\author{
${ }^{1}$ Comenius University, Bratislava, Slovakia \\ ${ }^{2}$ Military Institute (Engineering and Technical) of Military Academy of Material and Technical Support named \\ after General A.V. Khrulev of the Ministry of Defense of the Russian Federation, Saint Petersburg, Russia \\ *Corresponding author. Email: pyuma@yandex.ru
}

\begin{abstract}
In this article the notional, figurative and evaluative components of the concept "war" are described as they are introduced in Internet statuses in contemporary Russian culture. The analysis of Internet statuses about war shows that the concept under consideration, being very important in contemporary Russian linguistic culture, has a strongly negative evaluative component which is semantically based on the description of consequences of war. Together with some traditional semantic components this concept has developed some new meanings in modern Russian culture.
\end{abstract}

Keywords: Concept, Internet status, Notional component, Figurative component, Evaluative component, War.

\section{INTRODUCTION}

The theme of war has always occupied and still occupies a significant place in the worldview of man. This is due to the fact that almost in the fate of every generation of people there were wars and conflicts. The concept "war" has not lost its significance in modern culture, but, in our opinion, it has acquired some additional semantic characteristics. As a result, the study of the concept "war" in the modern Russian language seems relevant to us. This concept in people's consciousness is semantically and logically correlated and opposed to the concept "peace".

There is a binary opposition between these concepts, based on their natural and cultural-social characteristics. Peace as a state of absence of enmity, quarrel, and presence of harmony is antonymous with the concept "war" as an armed struggle between two or more states, peoples, tribes, or social groups within a state. At the same time, it is impossible not to note the complexity of the existing relationship between these two concepts. The concepts "war" and "peace" manifest themselves not only as antagonistic concepts. Their similarity lies in general characteristics that are realized both in the minds of people and in the language material. E. A. Golubenko comes to the conclusion that it is the concept "war", not "peace", which has a higher level of frequency and expressiveness in the minds of native speakers of Russian, English, and Japanese. This is not surprising, since it is well known that emotionally negatively colored phenomena, objects, and subjects cause a greater emotional response in the minds of native speakers of a particular language [4]. The universal concept "war" is significant in Russian linguistic culture. This confirms the multiplicity of basic signs-representatives of this concept, the presence of their word-forming derivatives, numerous synonyms, as well as their vivid representation at the phraseological level.

\section{ETYMOLOGICAL AND SEMANTIC ANALYSIS OF THE KEY WORD OF THE CONCEPT "WAR"}

War is one of the oldest and most common ways of appropriating someone else's territory, so 
we observe that the key word of this concept is represented in dictionaries by a variety of meanings: for the first time it was found in written monuments of the XI century in the meaning of "armed struggle of two or more peoples, states" [2].

The word "war" has many interpretations, and an analysis of its origin shows us that it descends from the Common Slavic era, which is reflected in various etymological dictionaries.

G. A. Krylov considers the etymology of this word as follows: "War. A common Slavic word formed from the noun вой — "warrior". It is related to the Latin venari - "to hunt", to the Old German weida - "hunting" [9].

A.V. Semenov points to the following origin of the word "war": Old Russian — воина, Old Slavic - воина, Common Slavic — vojьna. The noun "war" is Slavic in origin. For the first time it is found in written monuments of the XI century in the meaning of "armed struggle of two or more peoples, states" [10].

In the etymological dictionary of M. Fasmer, the following entry is given: "war, Ukrainian. війнá, Russian-Church Slavonic. воина, Bulgarian. война́, Slovenian. vójna, Czech republic, slvc. vojna, Polish. wojna. It is related to во́ин and such like concepts" [14].

In the dictionary of N. M. Shansky there is the following article: "War. Common Slavic. Formed with the help of the suf. -ьна (> на) от вой "воин" "warrior". Of the same root as вина, lit. výti "to chase, to pursue" , etc. Bou > вой Voi > "howl". In the word-formation plan is similar to $\underline{\sigma o u ̆ ~ " f i g h t ", ~ c f . ~}$ бить - бой "beat-fight" and *viti "hunt, chase") вой "howl""[16].

P. E. Chernykh in the "Essay of Russian Historical Lexicology "notes that first people had weapons, and then wars began: "Since ancient times, such words as вой,, eojeeoda, plk (root, possibly pel), войско “army" (by origin-an adjective with the suffix-ьск) are common Slavic words) > война; еојеeатu, борнити, борнъ (Russian. боронь); cf. in the Word about Igor's regiment: "на стоиши боРони" [cf. the Old Slavic Брань "Battle", from which a little later and the ругань "battle-swearing"; cf. lit.. Bàrti- бранить "scold" (original meaning: "What is pricked with": Lat ferire-prick, etc.; therefore, first "weapons", then - "battle", "war")" [15].

In the" Explanatory Dictionary of the Living Great Russian language " by V. I. Dal, several meanings of the word "war" are given: 1) war (war, to fight from to beat, slaughter, to fight, as probably both the boyar, and the voivode or militant); 2) discord between states; 3) military battle between states; 4) international warfare [5].

Thus, the analysis of entries from explanatory dictionaries of the Russian language allows us to distinguish the following series of meanings of the word "war":

- Armed struggle between States or peoples; struggle within a State

- A state of enmity; a struggle between someone, with something; a hostile relationship with someone, with something

- Actions that lead to the destruction of someone, something

- Relations of conflict between states, while both sides can use the means of economic and ideological influence

- Irreconcilable opposition; disagreement;

- Quarrel; rivalry

To consider the meaning of the word "war" in more detail, let us turn to the dictionaries of synonyms of the Russian language.

The dictionary edited by A. P. Evgenieva contains the following synonymic series: "Война, брань - War, battle (poet.). Брань is used in the modern language only in solemn speech. War is the continuation by means of violence of the policy pursued by the ruling classes of the belligerent Powers long before the war (Lenin on the "MPRA program"). When the god of swords and battle rises from the bed of rest, the loud challenge will burst, Then I will leave the world of fields. Pushkin, Orlov. In the first half of the XIX century, the obsolete word рать - "army" was occasionally used as a synonym. [Daniel] was sometimes in the рать "war", sometimes at peace with his neighbors, taking advantage of everything. N. Polevoy, History of the Russian people, book IV, chapter II." [6].

In the dictionary of synonyms edited by A. S. Gavrilova, the word "war" is also presented to us as: "struggle, clash, military actions, campaign, campaign, invasion, blockade, bombardment" [3]

In the dictionary of synonyms edited by $\mathrm{N}$. Abramov, a similar series of synonyms is distinguished: "War, struggle; clash; campaign, campaign, invasion, blockade, bombardment. War: 
internal, external, newspaper, bloody, internecine, sea, land, offensive, partisan" [2].

From the given data of etymological and explanatory dictionaries, it is clear that the lexeme "war" has a common Slavic origin and goes back to such words as "hunt", "chase, pursue", "beat - fight", "scold" and is represented by a variety of meanings, such as: armed struggle between states or peoples; struggle within the state; state of enmity; struggle between someone; actions that lead to the destruction of someone, something; relations of conflict between states; irreconcilable confrontation; disagreement; quarrel; rivalry.

Using the analysis of synonymic dictionaries, we have identified the following equivalents of this word: battle, army, struggle, clash, campaign, campaign, invasion, blockade, bombardment.

\section{SEMANTIC ANALYSIS OF INTERNET STATUSES ABOUT "WAR" IN MODERN RUSSIAN LINGUISTIC CULTURE}

In our opinion, the characteristics of the concept "war" in modern Russian linguistic culture can be identified on the basis of Internet statuses, since they clearly reflect the consciousness of the carriers of modern linguistic culture.

The Internet status is usually posted by a person in one of the social networks on the Internet page of the "profile". When someone posts an Internet status on a social network, he / she is waiting for a reaction from the public (those people who follow his / her "profile" in the social network or those people who are "invited" by the social network algorithm (targeting) to view the update of the Internet status of a certain person). If a person's Internet status causes surprise, delight, or other emotions, it serves as an incentive for communication between the source of the status creation and the potential addressee. Initially, such a phenomenon as the Internet status was conceived to convey the mood in which the person who publishes it is. N. I. Zrazheska calls the Internet status "a kind of motto of a person on the Internet, his "identifier" [7].

Usually, such statuses do not exceed three lines in length. The content plan of the Internet status is either a philosophical thought, a logical conclusion, or a description of the emotional and psychological state of a person.
Internet statuses, due to the limited number of characters in any social network, can not be too long, which means that they must be concise, bright emotionally and ironic. "As one of the forms of evaluative, critical and emotional development of the picture of the world, irony contributes to the expression of the author's individuality, creative position, and worldview. An ironic worldview can also be considered as a state of mind that allows people not to take too seriously banal statements and stereotypes"[1] ${ }^{102}$. Any status is intended to encourage the recipient to initiate a dialogue or any other emotional response.

Most often, Internet statuses relate to one of the following areas of life: relationships, work, study, household habits of a person, definition of feelings or emotions. Therefore, phraseological units, catch phrases, and aphorisms often become Internet statuses.

According to the well-known Russian linguist V. I. Karasik, the concept has notional, figurative and evaluative components [8]. We have identified the following components of the concept "war" based on the material of Internet statuses.

\subsection{Notional and Figurative Components of the Concept "War" in Modern Russian Linguistic Culture According to the Analysis of Internet Statuses}

The notional component of the concept "war" is presented as follows.

- War is death, murder, and bloodshed.

- Anyone who has ever looked into the glassy eyes of a soldier dying on the battlefield will think twice before starting a war.

- War is murder. And no matter how many people come together to commit murder, and no matter what they call themselves, murder is still the worst sin in the world.

- ...we must protect the world not with blood, but with friendship and love [12].

- War is evil, grief, tragedy, misfortune.

- War is a tragedy for everyone, but it makes a person feel life keenly and pushes him/her with all his/her strength to grasp this life [11].

- Even a victorious war is an evil that must be prevented by the wisdom of the nations. 
- War destroys our lives, it leads to the fatal inevitability of an unhappy fate [13].

- War is fear.

- Do not believe those who say that the war is not terrible. It's always scary... courage is when you overcome the animal horror and go forward [12].

- War is not only a threat to peace, but also keeps all of humanity in fear [13].

- War is destruction and disaster.

- War imposes its own values and destroys everything that was created by us.

- War is like a natural disaster, weighing down on you, and to stay alive, you try to get out.

- I do not know what weapons we will fight in the 3rd World War, but in the 4th World War we will fight with sticks and stones [11].

- War is a crime against humanity, lawlessness.

- War is a crime against humanity committed by humanity itself [13].

- War is a crime committed by politicians.

- When weapons rattle, the laws are silent [11].

- War - an interesting story and art.

- War is a damned interesting story; peace is a very boring read."

- War is an art, and art cannot be explained with clear formulas [13].

As it is seen from the Internet statuses analyzed by us the notional component of the concept "war" is not always represented by the definition of war as a bad, inhuman, immoral phenomenon. War is considered as barbarism and evil on the one hand, but on the other hand, as a sacred duty (in the case of defensive war), an interesting story and art.

It can be assumed that the positive connotations in this concept are caused by such properties of Internet statuses as irony and paradox. A person who publishes such statuses with a positive assessment of war, unconditionally expects an instant emotional reaction from readers.

The figurative component of the concept "war" is represented by a comparison of war with the kingdom of wild animals and associations with the black sky.
- People all wanted to understand where the war is and what is vile in it... It is in the terrible loneliness of the one who fights and the one who remains in the rear, in the shameful despair that engulfs everyone, and in the moral decline that eventually appears on the faces. The kingdom of the beasts has arrived.

- War turns into wild animals people born to live as brothers [12].

- Blue, blue sky. Gets blue and bluer the sky,

Interceptor planes over Siberia fly.

And they like in school mathematics draw a line

Will there between the nations stop lie?

From the state of Utah or Tennessee,

Like a ball in tennis.

A hydrogen bomb may be thrown,

For us it is well-known,

We will return something back

And the sky will become black [11].

\subsection{The Evaluative Component of the Concept "War" in Modern Russian Linguistic Culture According to the Analysis of Internet Statuses}

The evaluative component of the concept "war" is represented by the following semantic components.

- The conduct of war is often justified by the desire for peace.

- The more active the struggle for peace is, the faster it will lead to war.

- All wars on Earth begin with the most sincere statements about the desire for peace.

- The hatchet is most likely to be buried with bayonets [13].

- War is always associated with lies and injustice.

- The old declare war, and the young go to die.

- They never lie as much as they did during the war, after the hunt, and before the election."

- Wars are closely related to money and monetary interests. 
- Demolish money and wars will be stopped[13].

- Military conflicts are a political cover for those who skillfully empty the treasury blaming the war [11].

- Success in war depends not on weapons, but on money[13].

- Only those people who have not seen the war can admire it.

- War can only be enjoyed by those who have not seen it [12].

- It is easy to start a war, but it is difficult to finish and forget.

- For those who were in the war, it never ends.

- Wars start when they want, and end when they can [11].

- We must avoid wars and strive for creative peaceful work.

- No need for war, no need... Let's work better, think better, search better. The only real glory is the glory of labor.

- It is necessary to have great wisdom not to start wars.

- Be wise and do not declare war, and you will always remain undefeated, because the best war is not the one where the march of victories thunders, but the one that did not take place.

- War is barbaric when attacking a peaceful neighbor, but it is a sacred duty when defending the Homeland...

- In times of war, everyone dreams of peace, but no one has the courage to lay down their arms and say, "Enough! I've had enough!" [12].

- In any war, there are no winners, all losers.

- In the desert of war, flowers don't grow even for the victors.

- There are no winners in war - only losers [11].

- Defensive wars should be fought.

- In any war, the main thing is not victory, but the protection of people [13].

- Modern Russian people are very grateful to their ancestors who defeated fascism.

- Thank you, veterans of the Great War! Thank you for another spring! [12].

- Sports competition is like war.
- Football is a war of people with the ball and with each other... not for life, but for the cup!!!

- Hockey is a men's war, in which the battle is a holiday, and victory is happiness! [13].

- Love between the sexes is like war.

- Love is like war ... easy to start... hard to finish... impossible to forget!

- The war of the sexes is fought with traditional weapons. (Translation is of Julia Pogrebnyak).

\subsection{Semantic Characteristics of the Concept "War" in Modern Russian Linguistic Culture According to the Analysis of Internet Statuses}

From the analysis of Internet statuses, it is clear that the concept "war" in the language picture of the world of modern Russian people is associated with death, murder, bloodshed; evil, grief, tragedy, misfortune; fear; destruction, demolishment, disaster; crime against humanity, lawlessness.

However, rarely in the minds of native Russian speakers war is presented as a sacred duty (in the case of a defensive war), an interesting story and art.

The figurative component of the concept "war" is represented by a comparison of war with the kingdom of wild animals and associations with the black sky.

The evaluative component of the concept "war" is represented by the following semantic components:

- The conduct of war is often justified by the desire for peace.

- War is always associated with lies and injustice.

- Wars are closely related to money and monetary interests.

- Only those people who have not seen the war can admire it.

- It is easy to start a war, but it is difficult to finish and forget it.

- We must avoid wars and strive for creative peaceful work.

- It is necessary to have great wisdom not to start wars.

- In any war there are no winners, all losers. 
- Defensive wars should be conducted.

- Modern Russian people are very grateful to their ancestors who have defeated fascism.

- $\quad$ Sports competition is like war.

- Love between the sexes is like war.

The notional, figurative and evaluative components of the concept "war "in modern Russian linguistic culture are closely related, and the evaluative component is noticeably predominant, it seems to "grow" into the notional and figurative components of this concept, focusing our attention on the negative consequences of waging wars. This gives us a reason to attribute this concept to axiological ones.

\section{CHARACTERISTICS OF THE CONCEPT OF WAR ACCORDING TO THE DATA OF THE ASSOCIATIVE EXPERIMENT}

We conducted a survey of 150 cadets of the military institute in order to identify the characteristics of the concept "war". The cadets were asked the following questions:

- What is war, in your understanding?

- What do you associate with war?

- What is your attitude to war?

In the minds of most cadets, war is an armed conflict between states, a way of defending political interests. The respondents believe that war is the most terrible thing in this world.

The greatest number of associations that arise in the minds of respondents in connection to the word "war" are negative (88\%): death (150 people), destruction (84 people), fear (67 people), blood (65 people), pain (54 people), disaster (44 people), grief (37 people), hatred (37 people), tears (34 people), death (30 people), enmity (29 people), losses (28 people), horror (27 people), victims (24 people), cold (19 people), cruelty (18 people), chaos (7 people).

Among the positively colored associations, cadets distinguish the following $(9 \%)$ : victory (12 people), hero (7 people), feat (5 people), Motherland (4 people), courage ( 3 people), peace ( 3 people), Fatherland (2 people), patriotism (2 people).

The smallest number of associations with the word "war" is represented by a neutral-colored vocabulary $(3 \%)$ : weapons (5 people), battle (2 people), soldier (2 people), defense (1 person), offensive (1 person), liberation (1 person), explosion (1 person).

All respondents have a negative attitude to the war, consider it the hardest test for humanity, a disaster of incredible size, bringing death and destruction. They do not want the war to start again, but at the same time they are ready, if necessary, to stand up for their country and fulfill their duty.

\section{CONCLUSION}

From the above Internet statuses, it is clear that in modern Russian linguistic culture, the concept "war "is still closely related and at the same time opposed to the concept "peace". These two completely opposite concepts demonstrate the blurring of boundaries.

The lexeme "war" has a common Slavic origin and goes back to such words as "hunt"," chase, pursue"," beat - fight", "scold " and is represented by a variety of meanings, such as: armed struggle between states or peoples; struggle within the state; state of enmity; struggle between someone; actions that lead to the destruction of someone, something; relations of conflict between states; irreconcilable confrontation; disagreement; quarrel; rivalry.

From the analysis of Internet statuses and the associative experiment, it is clear that the concept "war" in the language picture of the world of modern Russian people is associated with death, murder, bloodshed; evil, grief, tragedy, misfortune; fear; destruction, destruction, disaster; crime against humanity, lawlessness.

However, rarely in the minds of native Russian speakers, war is presented as a sacred duty (in the case of a defensive war), an interesting story and art.

The figurative component of the concept "war" is represented by a comparison of war to the kingdom of wild animals and the black sky.

The evaluative component of the concept "war" is represented by the following semantic components: the causes of war are associated with the desire of evil and deceitful people to enrich themselves, one must have great wisdom not to start a war, because if it starts, it will bring death and suffering to all people. But defensive wars should be fought. Modern Russian people are very grateful to the defenders of the Fatherland, who have defeated fascism. In modern life, in the minds of Russian people, war is associated with sports 
competitions and with love between a man and a woman.

The analysis of the concept "war" shows that it belongs to the axiological ones, because the evaluative component noticeably prevails over notional and figurative ones. In modern Russian linguistic culture, the consequences of war - death, grief, misfortune, etc. - are sharply condemned.

War in its main meaning is present in the minds of native speakers, but at the same time, in conceptual terms, the boundaries of meanings are much expanded. War begins to show us different facets of relations between people, not always hiding behind the outer shell of the word discord and struggle, but often irony, and even humor. And this is not surprising, because irony is inherent in all modern culture. This once again shows us the impermanence of a concept: its dependence on time, country, people.

\section{AUTHORS' CONTRIBUTIONS}

Natalia Fursova is responsible for the analysis of word definitions in the dictionaries. Evgenia Nesterova identified the notional, figurative and evaluative components of the concept "war" on the basis of internet-statuses. Marina Vazhenina conducted the associative experiment and described its results. Olga Nozdryuk is responsible for the theoretical part of the article. Yulia Pogrebnyak contributed to revising and editing the whole article.

\section{REFERENCES}

[1] Abisheva V. T. Irony as a way of expressing a worldview position. // Bulletin of the Karaganda University. Series "Philology" № 3(79), 2015. - P. 101-105.

[2] Russian Dictionary of Synonyms and Similar Expressions, Moscow: Russkiye slovarii, 1999, p. 101-105. 2. Abramov N. Dictionary of Russian Synonyms and Similar Expressions. - URL: https://readli.net/slovar-russkihsinonimov-i-shodnyih-po-smyisluvyirazheniy/

[3] Gavrilova A. S. Dictionary of synonyms and antonyms of the modern Russian language. M.: Adelant, 2014. - 512 p.

[4] Golubenko E. A. Field organization of the concepts "war " and "peace" in the modern language picture of the world. - URL: https://cyberleninka.ru/article/n/polevaya- organizatsiya-kontseptov-voyna-i-mir-vsovremennoy-yazykovoy-kartine-mira/viewer

[5] Dal V. I. Explanatory dictionary of the living Great Russian language. - URL: https://azbyka.ru/otechnik/Spravochniki/tolko vyj-slovar-zhivogo-velikorusskogo-jazyka-v-idalja/

[6] Evgenieva A. P. Dictionary of synonyms of the Russian language: In 2 t. T. 1: C48 A-N / OR RAS. - M.: LLC "Astrel Publishing House": LLC "ACT Publishing House", 2003. $-680 \mathrm{p}$.

[7] Zrazhevskaya N. I. Communication on the Internet. Statuses as a means of popularizing aphorisms in the youth audience. Ural Philological Bulletin No. 2, 2012. - PP. 67- 69.

[8] Karasik V. I. Language circle: personality, concepts, discourse. - Volgograd: peremena, 2002. - $480 \mathrm{p}$.

[9] Krylov G. A. Etymological online dictionary. — URL: https://gufo.me/dict/krylov

[10] Semenov A.V. Etymological online dictionary. - URL: http://www.slovorod.ru/etymsemenov/

[11] Statuses about the war. - URL: https://statusas.ru/voennye-i-statusi/438statusi-o-woyne.html

[12] Statuses about the war: - URL: https://statuses-y.ru/statusy-pro-voynu

[13] Statuses about the war. - URL: https://statuses-y.ru/statusy-pro-voynu

[14] Fasmer M. Etymological online dictionary. URL: https://gufo.me/dict/vasmer

[15] Chernykh P. Ya. An essay on Russian Historical Lexicology: the Old Russian Period / P. Ya. Chernykh. - B. M.: Moscow University Press, 1956. - 243 p.

[16] Shansky N. M. Etymological online dictionary. - URL: https://gufo.me/dict/shansky love and in war, it is impossible to foresee everything. 